\title{
Possible consequences of an inability of plants to control manganese uptake
}

\author{
Philip J. White $\mathbb{B}$ - Konrad Neugebauer
}

Received: 19 October 2020 / Accepted: 26 March 2021 / Published online: 13 April 2021

(C) The Author(s) 2021

\begin{abstract}
Background This commentary presents several thoughts elicited by the observation of Lambers et al. (Plant Soil, 2021) in this Special Issue that the release of carboxylates by roots increases manganese (Mn) uptake by plants. Manganese is a plant nutrient, but is toxic in excess. Root cells take up Mn from the rhizosphere solution through non-specific transporters, whose activities are regulated by elements other than $\mathrm{Mn}$, and $\mathrm{Mn}$ phytoavailability in soil is also impacted by plant nutritional status of elements other than Mn. These complications could result in a plant being unable to respond appropriately to vagaries in Mn phytoavailability.

Scope The release of carboxylates by roots increases Mn phytoavailability and Mn uptake by plants. Lambers et al. (Plant Soil, 2021) suggest that this phenomenon might be used to identify plant species that release carboxylates into the rhizosphere in response to P deficiency. We suggest that, for the approach of Lambers and colleagues to be successful, it is necessary for all plants being compared (1) to be capable of increasing root Mn uptake and leaf Mn concentration should carboxylates be released, and increase these to a similar extent for the approach to be quantitative, and (2) to tolerate the greater tissue $\mathrm{Mn}$ concentrations resulting from increased Mn phytoavailability.
\end{abstract}

Responsible Editor: Antony Van der Ent.

P. J. White $(\bowtie) \cdot K$. Neugebauer

Ecological Sciences Department, The James Hutton Institute

Invergowrie, Dundee DD2 5DA, UK

e-mail: philip.white@hutton.ac.uk
Conclusions We observe (1) that the leaf Mn requirement, critical leaf Mn concentration for toxicity and capacity for Mn accumulation when grown hydroponically in a nutrient-replete solution are all positively correlated among plant species, which suggests that they might have evolved in parallel, and (2) that, although some orders containing species accumulating large shoot Mn concentrations are typically non-mycorrhizal and release carboxylates into the rhizosphere, such as the Proteales, many orders containing species with this trait are characterised by conventional mycorrhizal associations.

Keywords Carboxylates · Hyperaccumulator · Leaf manganese concentration $\cdot$ Mycorrhiza $\cdot$ Phosphorus acquisition · Phylogeny

\section{Commentary}

This commentary presents several thoughts elicited by the observation of Lambers et al. (2021) in this Special Issue that the release of carboxylates by roots increases manganese $(\mathrm{Mn})$ uptake by plants. Manganese $(\mathrm{Mn})$ is an essential plant micronutrient. It is required for the oxygen-evolving complex of photosystem II and for the activities of enzymes involved in photosynthesis, carbon and nitrogen metabolism, synthesis of RNA, and detoxification of reactive oxygen species (Alejandro et al. 2020; Schmidt and Husted 2019; White and Pongrac 2017). Tissue Mn concentrations greater than $10-20 \mathrm{mg} \mathrm{kg}^{-1}$ dry matter (DM) are generally considered adequate for optimal growth, development and 
fecundity of crop species (White and Pongrac 2017). However, Mn requirements differ greatly between crop species, ranging from $5 \mathrm{mg} \mathrm{kg}^{-1} \mathrm{DM}$ for Nandina domestica Thunb. (Berberidaceae, Ranunculales) to $1400 \mathrm{mg} \mathrm{kg}^{-1} \mathrm{DM}$ for Ilex pernyi Franch. (Aquifoliaceae; Aquifoliales) (Fig. 1b; Mills and Jones 1996). Although tissue Mn concentrations greater than about $100-200 \mathrm{mg} \mathrm{kg}^{-1} \mathrm{DM}$ can be toxic to many crop species, there is considerable variation among plant species in their tolerance of larger tissue Mn concentrations (Fig. 1b; Mills and Jones 1996) and some species have evolved an ability to hyperaccumulate Mn at concentrations above $10 \mathrm{~g} \mathrm{~kg}^{-1} \mathrm{DM}$ in their tissues (Reeves et al. 2017; White and Pongrac 2017). There appears to be a positive correlation between the leaf Mn concentration required by a crop species and the leaf $\mathrm{Mn}$ concentration that is toxic to it (Fig. $1 b ; R=0.71, n=$ 355 taxa, $\mathrm{P}<0.001$ ). More than 270 taxa (species) are known to hyperaccumulate $\mathrm{Mn}$ in their shoots (Fig. 1a; Gei et al. 2020; McLay et al. 2018; Reeves et al. 2017; van der Ent et al. 2018, 2019; White and Pongrac 2017). Angiosperm orders (and families) with a large number of known Mn hyperaccumulators include: Malpighiales (Phyllanthaceae, Cunoniaceae, Salicaceae, Euphorbiaceae), Myrtales (Myrtaceae), Ericales (Sapotaceae, Ericaceae), Gentianales (Rubiaceae, Apocynaceae), and Proteales (Proteaceae) (Fig. 1a; Gei et al. 2020; McLay et al. 2018; Reeves et al. 2017; van der Ent et al. 2018, 2019; White and Pongrac 2017).

Manganese is acquired from the rhizosphere solution as $\mathrm{Mn}^{2+}$ by roots of all plant species and also as $\mathrm{Mn}-$ phytosiderophore complexes by roots of graminaceous species (Alejandro et al. 2020; Curie et al. 2009; White and Pongrac 2017). In aerated soils Mn is present in the soil solution as $\mathrm{Mn}^{2+}$, although a significant amount can be present as organic complexes (Alejandro et al. 2020; White and Pongrac 2017). The $\mathrm{Mn}^{2+}$ concentration in the soil solution generally increases as $\mathrm{pH}$ falls and also increases as soils become anaerobic (Alejandro et al. 2020; Rengel 2015; White and Pongrac 2017). Thus, Mn toxicity often reduces plant growth and survival on acidic and waterlogged soils (Alejandro et al. 2020; Rengel 2015; White and Greenwood 2013). When plants have insufficient $\mathrm{Mn}$ to meet their physiological requirements, their roots often acidify the rhizosphere and release organic acids and enzymes capable of degrading organic compounds into the soil to increase Mn phytoavailability (Alejandro et al. 2020; George et al. 2014; Gherardi and Rengel 2004; Rengel 2015).
Fig. 1 a Phylogenetic relationship between angiosperm orders according to APGIV (2016) and (i) the average (arithmetic mean) manganese $(\mathrm{Mn})$ concentration in leaves considered to be sufficient for optimal growth of taxa (species) in an order (termed "requirement" here) calculated from data on 355 taxa presented by Mills and Jones (1996), (ii) the average (arithmetic mean) lowest Mn concentration in leaves considered to be toxic to taxa in an order (termed "tolerance" here) calculated from data on 355 taxa presented by Mills and Jones (1996), (iii) the average (arithmetic mean) Mn concentrations in leaves of species grown hydroponically in a nutrient-replete medium in an order (termed "capacity" here) calculated using data from 247 species grown in the experiments described by White et al. (2017) and tabulated by Neugebauer et al. (2018), and (iv) the number of taxa known to hyperaccumulate $\mathrm{Mn}$ in leaves to concentrations above $10 \mathrm{~g} \mathrm{~kg}^{-1}$ DM in their natural environment (Gei et al. 2020; McLay et al. 2018; Reeves et al. 2017; van der Ent et al. 2018; Ent et al. 2019; White and Pongrac 2017). Eleven Mn hyperaccumulators (three taxa in the Canellales, one taxon in the Paracryphiales, and seven taxa in the Santalales) are not shown. The colour coding is scaled from the smallest to the largest Mn concentrations of the orders (yellow $=$ smallest, orange $=$ intermediate, red $=$ largest). $\mathbf{b}$ The relationship between the leaf $\mathrm{Mn}$ concentrations required by crop taxa ([Mn $]_{\text {leaf }}$ "requirement") and the leaf Mn concentrations that are toxic to them ([Mn $]_{\text {leaf }}$ "tolerance") based on data for 355 taxa presented by Mills and Jones (1996). Statistics for the regression line are $\mathrm{R}=0.71, \mathrm{n}=355$ taxa, $\mathrm{P}<0.001$. c The relationship between the leaf Mn concentrations in species grown hydroponically in a nutrient-replete medium ([Mn $]_{\text {leaf }}$ "capacity") and the leaf Mn concentrations that are toxic to them ([Mn $]_{\text {leaf }}$ "tolerance") based on data for 31 taxa presented by both Mills and Jones (1996) and Neugebauer et al. (2018). Statistics for the regression line are $\mathrm{R}=0.61, \mathrm{n}=31, \mathrm{P}<0.001$

However, the expression of these acclimatory responses can differ within and among plant species (George et al. 2014; Rengel 2015). Furthermore, the acidification of the rhizosphere by roots and the release of organic acids, phytosiderophores and enzymes that degrade organic material is also induced in response to deficiencies of both macronutrients, such as $\mathrm{P}$, and micronutrients, such as $\mathrm{Fe}, \mathrm{Zn}$ and $\mathrm{Cu}$ (Rengel 2015; Wang et al. 2019; White and Pongrac 2017). Thus, the phytoavailability of Mn in the rhizosphere is often determined by the plant nutritional status of elements other than Mn.

The uptake of $\mathrm{Mn}^{2+}$ by root cells of all plant species is facilitated by members of the Zinc Regulated Transporter/Iron-Regulated Transporter (ZRT/IRT)-related Protein (ZIP) family, principally AtIRT1 in Arabidopsis thaliana, and members of the Natural Resistance Associated Macrophage Protein (NRAMP) family, principally NRAMP1 in Arabidopsis thaliana and OsNRAMP5 in rice (Alejandro et al. 2020; White and Pongrac 2017). Root cells of graminaceous species can 
(a)

Order

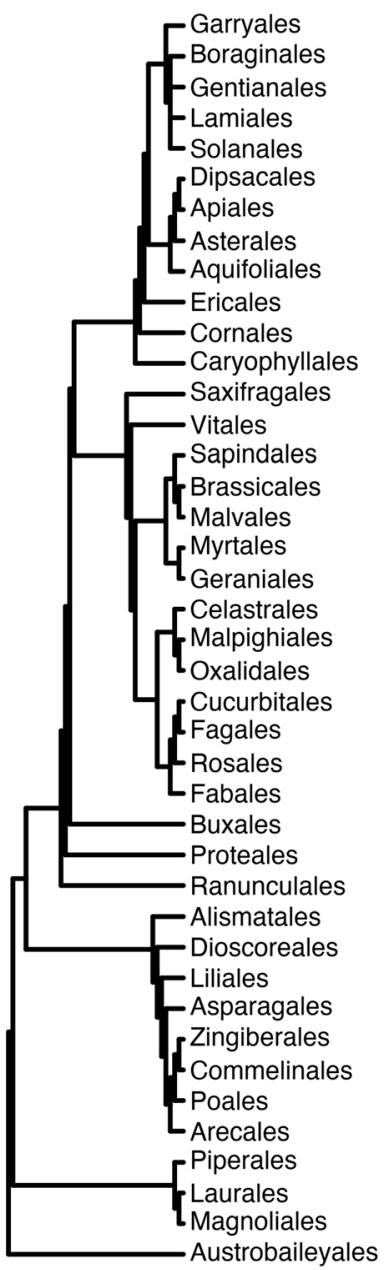

Requirement

Tolerance

Capacity

Hyper-

accumulators

\begin{tabular}{|c|c|c|}
\hline 191 & 325 & \\
\hline 105 & 122 & 97.5 \\
\hline 134.1 & 329.6 & \\
\hline 82.2 & 244.1 & 152.9 \\
\hline 38.7 & 281.5 & 198 \\
\hline 114.5 & 321.1 & 167.5 \\
\hline 83 & 401.3 & 134.2 \\
\hline 86.6 & 282.7 & 174.4 \\
\hline 645.5 & 1785.1 & \\
\hline 206.1 & 734.3 & 315.1 \\
\hline 56.9 & 222.9 & \\
\hline 73.6 & 371.3 & 217.6 \\
\hline 125.8 & 175.3 & 131.6 \\
\hline 93.8 & 193.8 & \\
\hline 97.7 & 398.4 & \\
\hline 38.9 & 179.3 & 143 \\
\hline 60.6 & 247.8 & 163.1 \\
\hline 65 & 369.3 & 278.9 \\
\hline & & 161.9 \\
\hline 51.5 & 260.7 & \\
\hline 37.9 & 230.8 & 93.3 \\
\hline & & 90.8 \\
\hline 50 & 270 & 193 \\
\hline 220.4 & 746.4 & 1052.2 \\
\hline 141.1 & 312.3 & 829.9 \\
\hline 36.6 & 152.1 & 159.7 \\
\hline 17 & 67 & \\
\hline 75.5 & 589.5 & 461.6 \\
\hline 175.2 & 341.7 & 170.5 \\
\hline 46.7 & 508.3 & 230.5 \\
\hline & & 330.4 \\
\hline 42.5 & 200 & 110.4 \\
\hline 53.8 & 253.7 & 171.6 \\
\hline 93 & 504.4 & 399.6 \\
\hline 142 & 251 & 65.8 \\
\hline 41 & 166.9 & 149.9 \\
\hline 40.8 & 144.4 & 147.8 \\
\hline 140 & 256.7 & 88.2 \\
\hline 63.7 & 308.7 & 147.2 \\
\hline 147.5 & 473.1 & 230.9 \\
\hline 195.5 & 525 & \\
\hline
\end{tabular}

20

9

3

2

27

7

13

1

31

5

(b)

Tolerance vs. Requirement

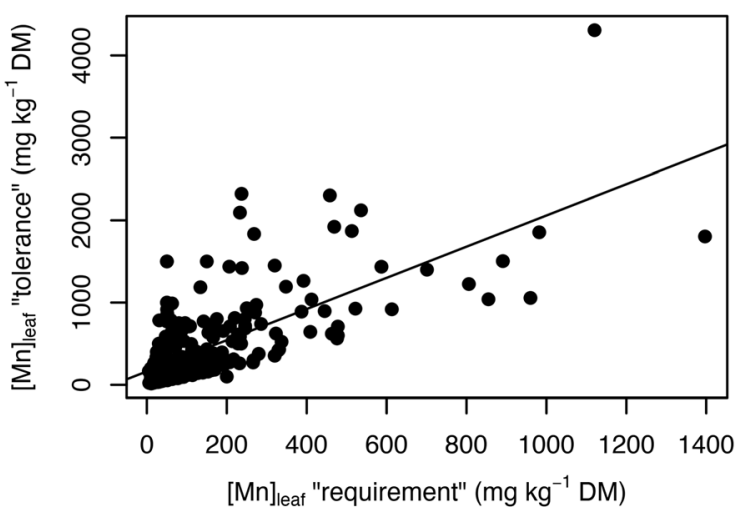

(c)

Tolerance vs. Capacity

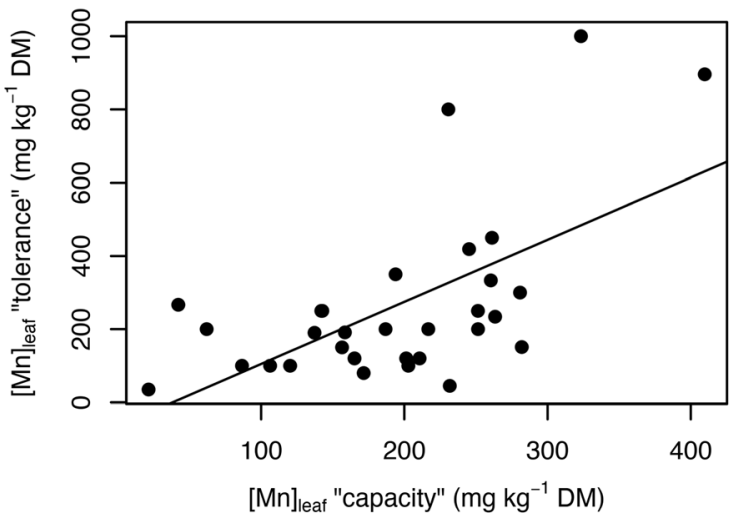


also take up $\mathrm{Mn}^{2+}$ as phytosiderophore complexes, catalysed by members of the Yellow Stripe-Like (YSL) protein family, principally OsYSL6 in rice (Alejandro et al. 2020; White and Pongrac 2017). It is noteworthy that these transporters are all non-selective and that the genes encoding them are regulated in response to plant nutritional status. For example, AtIRT1 is permeable to $\mathrm{Mn}, \mathrm{Fe}, \mathrm{Zn}, \mathrm{Cu}, \mathrm{Co}$ and $\mathrm{Ni}$ and the expression of AtIRT1 is upregulated by Fe deficiency; AtNRAMP1 and OsNRAMP5 are permeable to $\mathrm{Mn}, \mathrm{Fe}$ and $\mathrm{Cd}$ and the expression of AtNRAMP1 is upregulated by $\mathrm{Mn}$ and $\mathrm{Fe}$ deficiencies whereas that of OSNRAMP5 is upregulated by Fe and Zn deficiencies but unaffected by Mn deficiency; and OsYSL6 likely transports a variety of transitionmetal / phytosiderophore chelates (Alejandro et al. 2020; White and Pongrac 2017). It is possible that $\mathrm{Mn}^{2+}$ also enters root cells through non-selective cation channels (White and Pongrac 2017). Thus, the capacity for Mn uptake by root cells is often determined by the plant nutritional status of other elements. In particular, Mn uptake capacity is increased by $\mathrm{Fe}, \mathrm{Zn}$ and $\mathrm{S}$ deficiencies (Neugebauer et al. 2018; Pii et al. 2015; Stich et al. 2020) and also by Fe deficiencies induced by excess divalent cations. The lack of specificity of transporters catalysing Mn uptake is often cited as a possible reason for correlations among $\mathrm{Mn}, \mathrm{Zn}, \mathrm{Fe}$ and $\mathrm{Cu}$ in their accumulation by plants (Neugebauer et al. 2018) and it is perhaps noteworthy that genotypes of, for example, barley, with greater ability to tolerate soil Mn limitation not only have greater leaf $\mathrm{Mn}$ concentrations, but also greater leaf $\mathrm{Zn}$ and $\mathrm{Cu}$ concentrations than other genotypes when grown hydroponically (Schmidt et al. 2019).

Manganese is loaded into the xylem by $\mathrm{H}^{+}$-coupled antiporters, such as OsMTP9 in rice (Alejandro et al. 2020). The expression of OsMTP9 is unaffected by Mn deficiency, although its orthologs in other plant species are often down-regulated by $\mathrm{Mn}$ or $\mathrm{Zn}$ deficiency (Alejandro et al. 2020). In the xylem sap $\mathrm{Mn}$ is present as $\mathrm{Mn}^{2+}$ and as Mn-complexes with organic acid anions, such as citrate and malate, or nicotianamine (Curie et al. 2009; Welch 1995). Manganese follows the transpiration stream and is thought to be taken up by shoot cells as $\mathrm{Mn}^{2+}$ by members of the ZIP family (Alejandro et al. 2020; White and Pongrac 2017). Manganese is relatively immobile in the phloem (White 2012) and shoot Mn concentrations are generally larger than root $\mathrm{Mn}$ concentrations in most plants (Neugebauer et al. 2020). Thus, Mn deficiencies often originate in developing shoot tissues and Mn toxicities occur in older leaves where $\mathrm{Mn}$ is accumulated
(Alejandro et al. 2020; White and Pongrac 2017). Shoot Mn concentration, as a proxy for the capacity of a plant to take up Mn and translocate it to the shoot in the xylem, appears to differ among plant species growing in nutrientreplete media, as exemplified in studies using hydroponics systems (Fig. 1c; Neugebauer et al. 2018). There appears to be a positive correlation between the shoot Mn concentrations of plant species grown hydroponically in a nutrient-replete medium and both the Mn concentration required by these plant species $(\mathrm{R}=0.51, \mathrm{n}=31, \mathrm{P}=$ $0.004)$ and the leaf Mn concentration that would be toxic to them (Fig. 1c; $\mathrm{R}=0.61, \mathrm{n}=31, \mathrm{P}<0.001$ ).

An inability to respond effectively to vagaries in the $\mathrm{Mn}$ concentration in the soil solution might result from (1) the phytoavailability of $\mathrm{Mn}$ in the soil solution being regulated by the plant nutritional status of elements other than Mn, (2) the lack of specificity of transporters facilitating $\mathrm{Mn}$ uptake by root cells, and (3) the regulation of Mn-uptake capacity by the plant nutritional status of elements other than Mn. This could result in a greater susceptibility to both Mn deficiency and Mn toxicity, depending on soil properties and environmental conditions. In particular, should either Mn phytoavailability or the Mn uptake capacity be increased in response to nutrient deficiencies of elements other than Mn, this might necessitate greater tissue Mn tolerance of species growing on soils where these deficiencies occur to allow them to survive.

In this Special Issue of Plant and Soil, Lambers et al. (2021) discuss whether leaf Mn concentrations can be used as a tool to assess belowground functioning in phosphorusimpoverished environments. The rationale for this suggestion is founded on the observation that the release of carboxylates into the rhizosphere in response to $\mathrm{P}$ deficiency can increase Mn uptake by plants (Lambers et al. 2015). The authors combined data for leaf Mn concentration, root functional type and environmental variables from 727 species collected at 66 sites in Australia and New Zealand. They observed (1) that, in general, non-mycorrhizal plants that released carboxylates had larger (site-adjusted) leaf Mn concentrations than mycorrhizal plants when grown in soils with low P availability, but (2) that leaf Mn concentration did not provide information about root functional types under seasonally-waterlogged conditions, when Fe phytoavailability is high. The first observation is consistent with the hypothesis that Mn phytoavailability is increased by the release of carboxylates upon P deficiency, which results in greater root Mn uptake and leaf Mn concentration. The second observation is consistent with the hypothesis that high Fe phytoavailability greatly 
reduces the capacity for Mn uptake by root cells and, therefore, any increase in Mn phytoavailability produced by the release of carboxylates upon $\mathrm{P}$ deficiency has negligible effect on root Mn uptake and leaf Mn concentration. Nevertheless, it would appear that several assumptions must be fulfilled for the use of leaf Mn concentration as a proxy for root functional type to work. One assumption is that all plant species circumscribed in a comparative study are capable of increasing root Mn uptake and leaf $\mathrm{Mn}$ concentration should carboxylates be released by roots, and increase these to a similar extent for the approach to be quantitative. A second assumption is that all plant species must be able to tolerate (survive) the greater tissue $\mathrm{Mn}$ concentration resulting from the increased $\mathrm{Mn}$ phytoavailability, although it should be noted that, on severely P-impoverished soils, Mn is often limiting and leaf Mn concentrations would not reach toxic concentrations. These assumptions might be tested in future experiments. It is noteworthy that the carboxylate concentration in the rhizosheath of chickpea genotypes is directly correlated with foliar Mn concentrations under low phosphorus supply (Pang et al. 2018).

If the ability of plants to control Mn uptake and shoot $\mathrm{Mn}$ concentration is compromised when they are subject to common environmental challenges (e.g., low P soils, alkaline soils with low micronutrient phytoavailability, flooded soils), then it might be anticipated that plants from such environments would have evolved low $\mathrm{Mn}$ requirements and greater tissue $\mathrm{Mn}$ tolerance. The significant positive correlation between the shoot Mn concentration of plants grown hydroponically in a nutrientreplete medium and the tissue $\mathrm{Mn}$ concentration that would be toxic to these species, suggests that Mn uptake capacity and tissue Mn tolerance evolved together. This is consistent with the evolution of Mn hyperaccumulation through allelopathy to competitors and protection against pests and pathogens (Boyd 2007). Interestingly, the known Mn-hyperaccumulators exhibit a variety of root functional types. Although the Proteales that hyperaccumulate Mn form typical cluster-roots that release carboxylates in soils with low $\mathrm{P}$ availability (Lambers et al. 2021), members of other orders that include species that hyperaccumulate $\mathrm{Mn}$, such as Malpighiales, Myrtales, Ericales and Gentianales, typically form mycorrhizal associations (Brundrett 2009). The large Mn uptake of some members of these orders could result from the high phytoavailability of $\mathrm{Mn}$ in the soils on which they grow, either because of their low $\mathrm{pH}$ or because of the underlying (serpentine) geology, but many species that hyperaccumulate $\mathrm{Mn}$ grow on soils without abnormally large Mn concentrations (van der Ent et al. 2019). It is noteworthy, therefore, that some species from these orders are mycorrhizal but also release carboxylates, such as species in the genera Phytolacca (Malpighiales) and Vaccinium (Ericales) (DeGroote et al. 2018; Lambers et al.2015; Millaleo et al. 2020).

Author contributions The authors co-conceived and co-wrote the manuscript.

Funding Work at the James Hutton Institute is supported by the Rural and Environment Science and Analytical Services Division (RESAS) of the Scottish Government. We thank colleagues from COST Action CA19116 "Trace Metal Metabolism in Plants" for valuable discussions.

Data availability All data can be found in the sources cited.

Code availability Not applicable.

\section{Declarations}

Conflict of interest The authors declare no conflicts of interest.

Open Access This article is licensed under a Creative Commons Attribution 4.0 International License, which permits use, sharing, adaptation, distribution and reproduction in any medium or format, as long as you give appropriate credit to the original author(s) and the source, provide a link to the Creative Commons licence, and indicate if changes were made. The images or other third party material in this article are included in the article's Creative Commons licence, unless indicated otherwise in a credit line to the material. If material is not included in the article's Creative Commons licence and your intended use is not permitted by statutory regulation or exceeds the permitted use, you will need to obtain permission directly from the copyright holder. To view a copy of this licence, visit http://creativecommons.org/licenses/by/4.0/.

\section{References}

Alejandro S, Höller S, Meier B, Peiter E (2020) Manganese in plants: from acquisition to subcellular allocation. Front Plant Sci 11:300. https://doi.org/10.3389/fpls.2020.00300

Angiosperm Phylogeny Group IV [APGIV] (2016) An update of the angiosperm phylogeny group classification for the orders and families of flowering plants: APG IV. Bot J Linn Soc 181:1-20. https://doi.org/10.1111/boj.12385

Boyd RS (2007) The defense hypothesis of elemental hyperaccumulation: status, challenges and new directions. Plant Soil 293:153-176. https://doi.org/10.1007/s11104007-9240-6 
Brundrett MC (2009) Mycorrhizal associations and other means of nutrition of vascular plants: understanding the global diversity of host plants by resolving conflicting information and developing reliable means of diagnosis. Plant Soil 320:3777. https://doi.org/10.1007/s11104-008-9877-9

Curie C, Cassin G, Couch D et al (2009) Metal movement within the plant: contribution of nicotianamine and yellow stripe 1like transporters. Ann Bot 103:1-11. https://doi.org/10.1093 /aob/men207

DeGroote KV, McCartha GL, Pollard AJ (2018) Interactions of the manganese hyperaccumulator Phytolacca americana L. with soil $\mathrm{pH}$ and phosphate. Ecol Res 33:749-755. https://doi.org/10.1007/s11284-017-1547-z

Gei V, Isnard S, Erskine PD, Guillaume Echevarria G, Fogliani B, Jafré T, van der Ent A (2020) A systematic assessment of the occurrence of trace element hyperaccumulation in the flora of New Caledonia. Bot J Linn Soc 194:1-22. https://doi. org/10.1093/botlinnean/boaa029

George TS, French AS, Brown LK, Karley AJ, White PJ, Ramsay L, Daniell TJ (2014) Genotypic variation in the ability of landraces and commercial cereal varieties to avoid manganese deficiency in soils with limited manganese availability: is there a role for root-exuded phytases? Physiol Plant 151: 243-256. https://doi.org/10.1111/ppl.12151

Gherardi MJ, Rengel Z (2004) The effect of manganese supply on exudation of carboxylates by roots of lucerne (Medicago sativa). Plant Soil 260:271-282. https://doi.org/10.1023 /b:plso.0000030182.11473.3b

Lambers H, Hayes PE, Laliberté E, Oliveira RS, Turner BL (2015) Leaf manganese accumulation and phosphorus-acquisition efficiency. Trends Plant Sci 20:83-90. https://doi. org/10.1016/j.tplants.2014.10.007

Lambers H, Wright IJ, Guilherme Pereira C et al (2021) Leaf manganese concentrations as a tool to assess belowground plant functioning in phosphorus-impoverished environments. Plant Soil. https://doi.org/10.1007/s11104-020-04690-2

McLay T, Holmes GD, Forster PI, Hoebee SE, Fernando DR (2018) Phylogeny, biogeography and foliar manganese accumulation of Gossia (Myrtaceae). Aust Syst Bot 31:374 388. https://doi.org/10.1071/SB18018

Millaleo R, Alvear M, Aguilera P, González-Villagra J, de la Luz Mora M, Alberdi M, Reyes-Díaz M (2020) Mn toxicity differentially affects physiological and biochemical features in highbush blueberry (Vaccinium corymbosum L.) cultivars. J Soil Sci Plant Nutr. https://doi.org/10.1007/s42729-019-00166-0

Mills HA, Jones JB (1996) Plant analysis handbook II: A practical sampling, preparation, analysis, and interpretation guide. MicroMacro Publishing, Athens

Neugebauer K, Broadley MR, El-Serehy HA, George TS, McNicol JW, Moraes MF, White PJ (2018) Variation in the angiosperm ionome. Physiol Plant 163:306-322. https://doi. org/10.1111/ppl.12700

Neugebauer K, El-Serehy HA, George TS, McNicol JW, Moraes MF, Sorreano MCM, White PJ (2020) The influence of phylogeny and ecology on root, shoot and plant ionomes of fourteen native Brazilian species. Physiol Plant 168:790802. https://doi.org/10.1111/ppl.13018

Pang J, Ruchi B, Zhao H, Bansal R, Bohuon E, Lambers H, Ryan MH, Ranathunge K, Siddique KMH (2018) The carboxylatereleasing phosphorus-mobilising strategy could be proxied by foliar manganese concentration in a large set of chickpea germplasm under low phosphorus supply. New Phytol 219: 518-529. https://doi.org/10.1111/nph.15200

Pii Y, Cesco S, Mimmo T (2015) Shoot ionome to predict the synergism and antagonism between nutrients as affected by substrate and physiological status. Plant Physiol Biochem 94: 48-56. https://doi.org/10.1016/j.plaphy.2015.05.002

Reeves RD, Baker AJM, Jafré T, Erskine PD, Echevarria G, van der Ent A (2017) A global database for plants that hyperaccumulate metal and metalloid trace elements. New Phytol 218:407-411. https://doi.org/10.1111/nph.14907

Rengel Z (2015) Availability of Mn, Zn and Fe in the rhizosphere. J Soil Sci Plant Nutr 15:397-409. https://doi.org/10.4067 /S0718-95162015005000036

Schmidt SB, Husted S (2019) The biochemical properties of manganese in plants. Plants 8:381. https://doi.org/10.3390 /plants 8100381

Schmidt SB, George TS, Brown LK, Booth A, Wishart J, Hedley PE, Martin P, Russell J, Husted S (2019) Ancient barley landraces adapted to marginal soils demonstrate exceptional tolerance to manganese limitation. Ann Bot 123:831-843. https://doi.org/10.1093/aob/mcy215

Stich B, Benke A, Schmidt M, Urbany C, Shi R, von Wirén N (2020) The maize shoot ionome: Its interaction partners, predictive power, and genetic determinants. Plant Cell Environ 43:2095-2111. https://doi.org/10.1111/pce.13823

van der Ent A, Mulligan DR, Repin R, Erskine PD (2018) Foliar elemental profiles in the ultramafic flora of Kinabalu Park (Sabah, Malaysia). Ecol Res 33:659-674. https://doi. org/10.1007/s11284-018-1563-7

van der Ent A, Ocenar A, Tisserand R, Sugau JB, Erskine PD, Echevarria G (2019) Herbarium X-ray fluorescence screening for nickel, cobalt and manganese hyperaccumulation in the fora of Sabah (Malaysia, Borneo Island). J Geochem Explor 202:4958. https://doi.org/10.1038/s41598-019-40050-6

Wang W, Ding G-D, White PJ, Wang X-H, Jin K-M, Xu F-S, Shi L (2019) Mapping and cloning of quantitative trait loci for phosphorus efficiency in crops: opportunities and challenges. Plant Soil 439:91-112. https://doi.org/10.1007/s11104-018-3706-6

Welch RM (1995) Micronutrient nutrition of plants. Crit Rev Plant Sci 14:49-82. https://doi.org/10.1080/07352689509701922

White PJ (2012) Long-distance transport in the xylem and phloem. In: Marschner P (ed) Marschner's mineral nutrition of higher plants, 3rd edn. Academic, London, pp 49-70

White PJ, Greenwood DJ (2013) Properties and management of cationic elements for crop growth. In: Gregory PJ, Nortcliff S (eds) Soil conditions and plant growth. Blackwell Publishing, Oxford, pp 160-194

White PJ, Pongrac P (2017) Heavy-metal toxicity in plants. In: Shabala S (ed) Plant stress physiology, 2nd edn. CABI, Wallingford, pp 301-331

White PJ, Bowen HC, Broadley MR, El-Serehy HA, Neugebauer K, Taylor A, Thompson JA, Wright G (2017) Evolutionary origins of abnormally large shoot sodium accumulation in nonsaline environments within the Caryophyllales. New Phytol 214:284-293. https://doi.org/10.1111/nph.14370

Publisher's note Springer Nature remains neutral with regard to jurisdictional claims in published maps and institutional affiliations. 